\title{
The Grammar of Political Obligation
}

\author{
Thomas Fossen \\ Institute for Philosophy \\ Leiden University
}

Forthcoming in Politics, Philosophy \& Economics

\begin{abstract}
This essay presents a new way of conceptualizing the problem of political obligation. On the traditional 'normativist' framing of the issue, theorists' primary task is to secure the content and justification of political obligations, providing practically applicable moral knowledge. This paper develops an alternative, 'pragmatist' framing of the issue, by rehabilitating a frequently misunderstood essay by Hanna Pitkin and by recasting her argument in terms of the 'pragmatic turn' in recent philosophy, as articulated by Robert Brandom. From this perspective, the content and justification of political obligations cannot be determined in a way that is in principle separable from their application. This casts 'political obligation' not as a problem to be philosophically resolved, but as a political predicament that calls for a kind of practical engagement. The merit of this perspective is to draw our attention toward the conditions under which the problem appears as a lived predicament.
\end{abstract}

Keywords: political obligation; pragmatism; Robert Brandom; Hanna Pitkin; Ludwig Wittgenstein 
Anyone confronted with political authorities that claim to be entitled to his or her compliance is forced to take a stance - to recognize their claim as legitimate or reject it as mere imposition. The question of how to respond to a political authority's claim is a practical predicament that subjects address, implicitly or explicitly, reflectively or not, simply in being confronted with power. One can comply or resist, and do so wholeheartedly or reluctantly; and whichever one chooses, others (not least the respective authorities) will try to hold one responsible. Although it is sometimes possible to flee if power becomes unbearable, that too is a way of practically relating to it, of taking a stance and acting on it in a particular way. I take this to be a fundamental political predicament. One way of articulating it, which is familiar in political philosophy, is in terms of the 'problem of political obligation': are we bound to uphold and obey political authority, and if so why? Irrespective of how we answer this question, the authorities and (some of) our fellow subjects hold us to accountthey attribute obligations to us. But what (if anything) entitles us to attribute political obligations to ourselves and to one another?

My aim in this essay is not to resolve this predicament. Rather, I want to contrast two ways in which it can be framed or conceptualized. As it is usually understood, the problem of political obligation concerns the moral character of the relation between subjects and political authority: is it such that a subject is morally obligated to obey and uphold political authority? Or, more specifically, is there an obligation to obey the law? Subjects may have a sense of having obligations toward authorities, but are there really such political obligations? On the traditional framing of the issue, which I label 'normativism', we need a philosophical justification of political obligation, capable of functioning as an independent test of the sense of 
obligation (or lack thereof) of actual subjects. Questions concerning the content and justification of political obligations call for a philosophical solution (leaving, no doubt, a difficult task of application in practice).

This framing of the predicament and the associated task-description of political philosophy are often taken for granted. The apparent self-evidence of this picture of what is at stake should disappear, however, when we contrast it with an alternative. More importantly, doing so might cast the predicament in a different light. By drawing on Wittgensteinean currents of philosophy of language and political theory, I aim to show that it is possible to construe an alternative, 'pragmatist' framing of the political predicament. In fact, such a view was already articulated in an insightful but frequently misunderstood essay by Hanna Pitkin, which I take as my point of departure. This alternative perspective hinges on a 'pragmatic turn' in the philosophy of language, according to which meaning is understood in the first instance in terms of pragmatics (the 'use' of concepts in social practice, or what one does in claiming something) rather than semantics (the meaningful 'content' of concepts, or what is being claimed). From this perspective, political obligations can be seen as practical commitments toward authorities (and, arguably, fellow political subjects), according to which certain courses of action are appropriate and others inappropriate (obedience and resistance are paradigmatic examples). Being practically committed in this way is a matter of being held to account, by oneself or by others. Crucially, from this perspective, the content and justification of such practical commitments cannot be determined in a way that is in principle separable from their application. The predicament is not a problem that calls for a philosophical resolution, but rather a task that calls for a kind of performative engagement; contesting commitments politically, rather than securing them philosophically. Rather than 
focusing on the questions whether political obligations exist and what grounds them, this draws our attention in a different direction: What is it to distinguish in practice between genuine political obligations and a mere sense of obligation? What are the conditions under which this appears as a lived, practical predicament?

\section{Normativism: Securing genuine obligations}

Let me begin by briefly sketching what I take to be the predominant way of framing the problem of political obligation in the current debate. Recent years have seen increasing differentiation and sophistication in this discussion. ${ }^{1}$ My main interest here concerns the way the question is posed, rather than the specifics of the solutions that are put forward.

The first thing to note is that what is at stake is a basic predicament for political subjects. Political authority makes a claim on them, it prescribes or prohibits courses of action, often backed by a threat of coercion. For a subject facing such demands, the question arises: 'Should I obey? Is there anything more to this claim on my obedience than mere coercion?' But what is the philosophical problem at stake in this predicament? Typically, it is cast as a question of moral theory: is there a moral requirement for political subjects to obey? As John Simmons glosses the question in a study that has been very influential in framing and setting the agenda for the subsequent debate:

\footnotetext{
${ }^{1}$ For recent overviews, see Dagger (2007), Horton (2010), and Mokrosińska (2012). Many scholars now express skepticism about the prospects for a successfully showing the existence of political obligations (Buchanan, 2002: 696; Morris, 1998: 214; Simmons, 2001). For a recent, less skeptical view, see Klosko (2011).
} 
Many people feel, I think, that they are tied in a special way to their government, not just by "bonds of affection," but by moral bonds. While they complain loudly and often, and not without justification, of the shortcomings of government, they feel that they are nonetheless bound to support their country's political institutions and obey its laws, in ways that they are not bound to the corresponding institutions of other countries. Yet it is difficult to give any substance to this feeling of a special moral bond. It seems to me that the problem of political obligation is precisely the problem of explaining the nature and scope of such special moral bonds (if any such exist), and of determining who, if anyone, is constrained by them. (Simmons, 1979: 3-4)

The philosophical task, then, is to determine whether and under which conditions people actually have moral political obligations. Similarly, John Horton takes what is at stake to be a "moral bond between citizens and community" (Horton, 1992: 13):

"Philosophers have understood their task to be one of explaining the nature of this moral relationship; more specifically this has most usually been interpreted as seeking a moral justification for the authority of government and the obligations of citizens. Again, this has usually been thought to require the deriving of political obligation from one or more general principles or locating it within some more comprehensive moral theory." (Horton, 1992: 14-15)

The basic intuition underlying this way of framing the problem seems to be this: a mere sense that one is bound to obey authority is by itself problematic, because one's sense of obligation may not truly reflect what one morally ought to do; one may be deluded or mistaken or, worse, misled or cheated into accepting the coercive power one faces. This intuition is plausible; clearly, a mere sense that one is obligated to obey an authority may indeed be problematic in these ways. The contingencies of our actual experience (for instance, that one takes oneself to be a loyal citizen or an elected representative) are possibly pernicious because they might represent an 
imposition on us - and from a limited, bounded perspective we are unable to assess whether, objectively, they are. Subjects face, in other words, a predicament of distinguishing between spurious and genuine obligations, between a mere sense of obligation and the actual obligation itself.

One way of responding to this predicament is to search for a way of securing this distinction by reference to some valid normative principle, which might then enable subjects to distinguish in practice. An influential way of proceeding, proposed by Simmons, begins by distinguishing between "institutional" or "positional" obligations and "moral" obligations (Simmons, 1979: 21; cf. Gewirth, 1970: 80-81). Sometimes, the concept of obligation is used to indicate what someone ought to do in virtue of fulfilling a particular role within an institution or social practice. But taken by themselves, Simmons argues, obligations tied to a particular institution or practice have no "moral weight," because the particular institution or practice may itself be morally problematic (Simmons, 1979: 16-23). Something must be supplemented for a positional obligation to make a genuine normative claim on someone, and this additional consideration must be independent of the institution or practice at stake. As Simmons puts it: “The existence of a positional duty (i.e., someone's filling a position tied to certain duties) is a morally neutral fact. If a positional duty is binding on us, it is because there are grounds for a moral requirement to perform that positional duty which are independent of the position and the scheme which defines it." (Simmons, 1979: 21; cf. Gewirth, 1970: 62) The additional bit is then to be supplied by some general moral consideration or principle. ${ }^{2}$ The crux of the debate then comes down to

\footnotetext{
${ }^{2}$ Alan Gewirth makes a similar argument: "Thus the basic question of political obligation $[\ldots]$ is whether or not it satisfies the criteria which would make it a moral obligation." (Gewirth, 1970: 81)
} 
the question which principle or set of principles, if any, provides solid ground for distinguishing between genuine and spurious positional obligations. ${ }^{3}$

Let me call this type of approach 'normativism,' for lack of a better word. ${ }^{4}$ For purposes of this essay, normativism refers to a framing of the problem of political obligation as calling for a resolution by appeal to the right principles, and the associated task-description of political philosophy as focused on finding such principles capable of grounding political obligations. On this line of approach, political philosophy (insofar as it concerns political obligation) is primarily concerned with the theoretical justification (or refutation) of explicit norms. ${ }^{5}$ Normativist approaches to political obligation typically (though not always) address the problem in a moral register (recall the title of Simmons' influential study: Moral Principles and Political Obligations). ${ }^{6}$

To be clear, I do not mean to contrast normativism with a non-normative understanding of political obligation (I don't see what that could be). Rather, the

\footnotetext{
${ }^{3}$ My way of formulating this aim in terms of distinguishing between genuine obligation and a merely felt or attributed spurious sense of obligation emphasizes that it is in the first instance a practical question, rather than a metaphysical one, even though philosophers concerned with political obligation often formulate the question more abstractly in terms of the "existence" of obligations (as we've seen in the case of Simmons).

4 'Moralism' seems more problematic to me as an alternative, firstly because some normativist approaches appeal to another normative register, such as prudence (see also the discussion of Gilbert below), and secondly because it has the connotation of a kind of practical political attitude, rather than the intended meta-theoretical approach (though admittedly the latter is a problem for the 'pragmatist' label as well).

${ }^{5}$ Within political philosophy more widely, this task-description is highly contested. Alternate currents argue, in different ways, that political philosophy should orient itself in the first instance toward political practice, rather than moral justification. See, for example, Geuss (2008), Laden (2001), Rorty (1991), Tully (2002), or B Williams (2005).

${ }^{6}$ Alternatively, one might, for example, argue that a prudential grounding is sufficient.
} 
normativist interpretation of the predicament contrasts with the pragmatist approach articulated below in the way it philosophically takes up this inevitable normativity. To foreshadow briefly, whereas normativism focuses on grounding obligations in general principles, a pragmatist approach is more contextual, as well as opening more space for acknowledging and articulating the dimensions of political contestation involved.

It may help to clarify what I mean by normativism by briefly discussing 'associative' accounts of political obligation, which have recently received much attention. ${ }^{7}$ On such views, what is at stake in the problem of political obligation is one's political identity or membership in a political community. Sometimes, these theories are seen as recommending 'membership' as a moral principle that grounds political obligations, in contrast to, say, consent, gratitude, or fairness (Dagger, 2007; van der Vossen, 2011). But at least some of these accounts go further, reframing our understanding of the problem in interesting ways. I want to briefly discuss two such accounts, those of Margaret Gilbert, who denies that genuine political obligations are necessarily moral, and John Horton, who denies that the question calls for a philosophical resolution.

Gilbert argues that membership of a political society involves having genuine political obligations by virtue of the members being "jointly committed" to uphold their governing institutions (Gilbert, 2006). Interestingly, for her, showing political obligations to be genuine does require grounding them in moral principles. Such obligations give "sufficient" (but not "absolutely conclusive") reason to act in line with them, in a rationally binding sense that marks them off from inclination and selfinterest, but they are not moral requirements (Gilbert, 2006: 30-31). Her worry about calling political obligations moral is that it often remains obscure precisely what it

\footnotetext{
${ }^{7}$ For an overview, see Van der Vossen (2011).
} 
means for an obligation to qualify as a moral requirement (Gilbert, 2006: 21-24). On the one hand, committing to a very specific, theoretically stipulated conception of morality risks confusion by losing touch with intuitive notions of morality. On the other hand, operating with a vague, intuitive sense of morality risks obscuring the specific normative force of political obligations. "[I]f we restrict ourselves to the standard approach to political obligation in terms of moral requirement we stand to lose sight of an enormously consequential fact: the existence of a distinct realm of obligation.” (Gilbert, 2006: 295) I think Gilbert's worries capture something important: that, considering the philosophically contested character of conceptions of morality, treating morality as a given (by framing the predicament from the start as a moral problem) does not enhance our understanding of the questions subjects confront in the face of political authorities. Still, while Gilbert diverges from the mainstream in holding that political obligation need not be understood in moral terms, the structure of her approach is still normativistic in this respect: it aims to secure a distinction between genuine and spurious obligations, through a notion of joint commitment. Distinguishing between genuine and spurious obligations then appears to be a matter of applying this knowledge in particular cases, assessing whether a joint commitment is in place.

For Horton, too, political obligations are implied by an adequate understanding of membership of a political community (Horton, 2006, 2007b; cf. Vernon, 2007; Horton, 2007a). But he disputes that the main task of political philosophy with respect to political obligations is to provide them with a philosophical justification. He attempts not "straightforwardly to determine whether individuals have political obligations," but takes an approach that is "more interpretive or explanatory in intent," showing "what sense can be made of the idea 
that people have associative political obligations, and whether or not it can be shown to be irrational or necessarily immoral for people to think in terms of their having such obligations." (Horton, 2006: 428) Rather than seeking to secure a distinction between spurious and genuine obligation, he tries to defend the "intelligibility" of a particular kind of self-understanding with respect to a political authority, namely as obligated to obey and uphold certain political institutions (Horton, 2006: 428). This comes out most clearly when he points out that much of the criticism of the idea of associative obligation turns on a difference between felt obligations and real obligations. As Richard Dagger put it, often "the argument [for associative obligations] slides from the sense of obligation to the obligation itself." (Dagger, 2000: 108) And as we saw, Simmons holds that "associative, communal, role, or institutional obligations require external justification to be morally binding." (Simmons, 1996: 273 n. 50) These criticisms clearly echo the normativist demand for a way of securing the distinction between genuine and spurious obligations. Horton questions the force of these objections. He suggests that the need for an external justification is less pressing than it seems, because "the bare possibility of error has no independent weight." (Horton, 2006: 431) The point is essentially about what the default position is: for Horton, the default position is the sense of identification with a political community that he believes most people start with, whereas for Simmons this sense cannot have normative status for us without a philosophical grounding. ${ }^{8}$ Horton does not attempt to philosophically secure the distinction between genuine obligation and a mere sense of obligation; he tries to shift the burden of proof, putting the onus

\footnotetext{
${ }^{8}$ Simmons rightly warns against complacent acceptance of what people in general happen to believe. We cannot simply grant the "authority of shared moral experience" (Simmons, 1996: 249). But that point would only be a serious objection if Horton argued that we should rely on received moral sentiments uncritically.
} 
on the critic to show that a sense of identification or obligation is spurious (Horton, 2006: 434). Even if our sense of obligation may always turn out to be spurious, we can only start from the ground upon which we presently stand.

The pragmatist picture of the problem of political obligation I will draw shortly shares with Gilbert a rejection of the idea that political obligation must necessarily be understood in the first instance as moral (without committing to her social theory). And with Horton it shares a rejection of the idea that the task for theorists is to provide an external philosophical justification. As I aim to show, both points can be clearly understood if we frame the predicament in pragmatic terms. But before doing so, I will consider an illuminating and underappreciated dissident from the normativist picture of the problem of political obligation.

\section{$3 \quad$ Rereading Pitkin on the grammar of political obligation}

Hanna Pitkin's seminal two-part article “Obligation and Consent” $(1965,1966)$ raises the question whether someone who is confronted by political authority really needs a philosophical justification of the grounds of political obligation. Her view has been severely criticized — it is often given short shrift, dismissed in a couple of pages ${ }^{9}$ - yet it is worth pausing a moment to examine it, as well as its uptake in the literature.

Pitkin puts the core of her view thus:

To call something a legitimate authority is normally to imply that it ought to be obeyed. You cannot, without further rather elaborate explanation, maintain simultaneously both that this government has legitimate authority over you and that you have no obligation to

\footnotetext{
${ }^{9}$ See Pateman (1973, 1979: 27-30), Simmons (1979: 39-45, 1996: 253-255), Green (1990: 193-195), Mokrosińska (2012: 33-38), Knowles (2009: 175-176), Stark (2000: 323-324). A more subtle reading can be found in Flathman (1972: 88-111) and Horton (1992: 83-87).
} 
obey it. Thus if you say that you consent to it (recognize it as an authority), that statement itself is normally a recognition of the obligation to obey, at least at the moment it is uttered. Part of what "[legitimate-TF] authority" means is that those subject to it are obligated to obey. [...] [T]his doctrine tells us (something about) what legitimate authority is by reminding us of something about what "legitimate authority" means. But of course that is not yet to provide criteria for telling apart the two species-legitimate authority and mere coercion—when you encounter them in reality. (Pitkin, 1966: 39-40)

That legitimate authority ought to be obeyed, that it imposes obligations on subjects, Pitkin argues, is a matter of the "grammar" of the concepts involved (Pitkin, 1966: 39; cf. Glock, 1996: 150-155). As we'll see below, her point isn't a purely analytic or semantic one, although it may appear that way at first sight. Rather, she issues a reminder of the "meanings" of our political concepts in terms of their use, the role they have in social practice.

By making this socio-grammatical point, Pitkin wants to dispel the idea that there is a need to say something special about political obligations that shows why they oblige, something that explains why one is obligated to obey a legitimate government, apart from the fact that it is legitimate. If one is capable of distinguishing in practice between legitimate and illegitimate political authority, according to Pitkin, one does not need a further justification of why one would be obligated to obey or support a legitimate authority (though of course this is a big if). "[T]o the question why obligations oblige the only possible answer would seem to be that this is what the words mean." (Pitkin, 1966: 47) To demand such a justification, Pitkin suggests, is a symptom of confusion generated by the philosopher's preoccupations, rather than the predicaments experienced by political subjects.

Theorists of political obligation are understandably worried when they perceive their whole line of inquiry as being dismissed as resting on philosophical 
confusion, and this perhaps accounts for their vehement dismissal of Pitkin's view. After all, as I noted at the outset, political subjects face a real question in political relations - whether they ought to obey and uphold the authorities they face. Her critics think that Pitkin dismisses this question out of hand by proposing a formulation of what has become known in the literature as "the conceptual argument." This argument, briefly put, purports to derive from the mere meaning of terms like "political society" and "authority" the existence of binding obligations on actual political subjects. ${ }^{10}$ As it is stated, the conceptual argument is obviously problematic, as many have been quick to point out. One cannot from the mere meaning of terms like 'obligation' and 'legitimate authority' infer that real political subjects have obligations to obey whatever in practice purports to be a legitimate authority. On this reading of Pitkin, her emphasis on the conceptual connection between legitimate authority and political obligation is understood as an attempt to show that it is just obvious that citizens have political obligations and to stop questioning of actual authorities in the bud, or even to deny any conceptual space for it (Pateman, 1973; Mokrosińska, 2012: 33-38). So it is suggested that for Pitkin there is no genuine question of whether one ought to obey or not. But is that really what she is saying? Perhaps its obvious deficiency should make one wonder whether the position ascribed to Pitkin isn't a straw man. ${ }^{11}$

\footnotetext{
${ }^{10}$ See note 9, above. Pitkin's account is often mentioned in one breath with those of Macdonald (1940) and McPherson (1967) who are also, and more plausibly, taken to espouse the "conceptual argument." I think their positions are more vulnerable to this line of criticism and I will leave them aside.

${ }^{11}$ As Pitkin suggests in a different context (1972: 314): "If a theoretical position strikes us as obviously false or absurd, perhaps that is because we have not understood what the theorist is trying to say. It is well, before rejecting the position, to ask ourselves 'How could he have believed that?"”
} 
Pitkin's aim, as I understand it, is precisely the opposite: it is not to preclude criticism, but to propose a more fruitful and practical way of questioning by inducing political philosophers to orient themselves to the real, lived questions political subjects face when confronted by authorities (as in the examples she discusses of Socrates, an "ordinary criminal," an "American student engaging in civil disobedience," a "Mississippi Negro who decides to join a revolutionary group," a "South African Negro who decides to join a revolutionary group," and a "minor official in Nazi Germany, who continues to carry out his functions")(Pitkin, 1966: 40). To see this, we must get a clearer view of the confusion Pitkin diagnoses and see how she aims to redirect our attention to the lived predicament of political subjects.

Wherein, then, lies the confusion according to Pitkin? She suggests it is like the confusion of someone who asks "why does a promise bind me?" without recognizing that to make a promise simply is to bind oneself. Promising is a social practice. Binding oneself is something one must master in order to be able to make promises in the first place, but mastering promising does not involve knowing a justification for the bindingness of promises (Pitkin, 1966: 47). Similarly, the questions "why ought I obey even a legitimate government" or "why ought I ever obey any law" stem from a failure to notice that for a government to be legitimate is for it to deserve allegiance, and for a law to be valid is for it to be binding. Unfortunately, Pitkin does not distinguish here between political legitimacy and legal validity, which gives Simmons cause to object that "valid law" is tied conceptually only to legal, not political obligations (Simmons, 1979: 39-40); her point would be better put by speaking of "legitimate law" as she often but not consistently does for government and authority. 
Seen from a pragmatic perspective that accepts the Wittgensteinean point that meaning should be understood in terms of use, these claims are rather modest, or even trivial. If the argument is accepted, its practical implications are limited (as she mentions (Pitkin, 1966: 40, 45)) if by practical implications one means directly applicable answers or prescriptions, because pointing out that a legitimate authority is one that ought to be obeyed does not provide one with any reason for obedience or resistance in a particular case: "of course that is not yet to provide criteria for telling apart the two species - legitimate authority and mere coercion—when you encounter them in reality." (Pitkin, 1966: 39-40)

Pitkin suggests that the confusion disappears when one asks not for a general justification of political obligation, but rather for reasons for obeying political authority in particular cases. The significant practical question for political subjects is not how obligations arise but how we can distinguish between "legitimate political authority and mere coercion" in a specific situation (Pitkin, 1966: 39). "[T]here are a hundred reasons; there is no reason." (Pitkin, 1966: 47) So she by no means denies the practical predicament of distinguishing between legitimate and illegitimate authority, or genuine and spurious obligations. The point is not that these are not genuine questions, but that staring at the question of the grounds of obligations is not a fruitful way to take them up.

Then how are we to take up this predicament? Pitkin does not draw the conclusion that we need a moral theory to provide a definitive answer, but neither does she deny reasons or criteria a role in addressing situations as they come up. She wonders, and apparently remains undecided, whether political philosophers should formulate principles that subjects can apply. "One might argue, however, that such a theory [of political obligation] should at least tell him [a political subject] what sorts 
of considerations are relevant to his decision, direct his attention and tell him where to look." (Pitkin, 1966: 40) What she suggests, then, is that the task of theories may not be to resolve the predicament, but to draw our attention toward aspects of the situation that are pertinent for addressing it in practice. This concern drives her critique of consent-theory. Considering a broad range of cases in which the predicament arises, she argues that looking at one's prior consent does not seem to capture what is at stake: "It teaches him to look at himself (for his own consent) or at the people around him (for theirs), rather than at the merits of the government. [...] Thus the man who must choose is directed to the question: have I (we) consented to this?" (Pitkin, 1966: 40) Instead, Pitkin aims to redirect the attention of subjects confronting authorities to the "character of the government" and a wide range of further "social circumstances" (Pitkin, 1966: 40-42, 44-45, cf. 1965). ${ }^{12}$

I will go into this in more detail in the final section of this paper. For now, it is worth considering one more articulation Pitkin gives to the predicament, in terms of distinguishing between the normal and the exceptional:

But if normally law and authority oblige and resistance requires justification, and if normally judgment is to some extent subordinated to that of the authorities, and if revolutionary situations are precisely the ones that are not normal in these respects, then the crucial question seems to be: who is to say? Who is to say what times are normal and what times are not, when resistance is justified or even obligatory? (Pitkin, 1966: 51)

\footnotetext{
${ }^{12}$ In this light, it would be anachronistic (pace Cynthia Stark (2000)) to read what Pitkin calls her "doctrine of hypothetical consent"- the idea that a legitimate authority is one that one ought to consent to - as a version of hypothetical consent theory as developed for instance by Rawls and Scanlon, which is aimed precisely at formulating a set of moral principles. Rather, I think this formula is just meant to express the socio-grammatical point discussed above.
} 
Critics have been tempted by Pitkin's claim that "normally" political authority ought to be obeyed to attribute a conservative position to her. On my reading, however, her point about normality and exception isn't that most of the time authority simply ought to be obeyed, but rather reflects the fact that there is normally a defeasible claim to legitimacy. A claim to legitimacy requires a counterclaim to defeat it, or at least an “occasion for questioning" (Pitkin, 1966: 51). ${ }^{13}$ That it is defeasible points to the task for anyone of distinguishing the normal from the exceptional in critical moments. This leaves conceptual room even for the anarchist position that any power claiming to be a legitimate political authority is disingenuous and should be rejected (in which case any relation of rule is exceptional). But a cause for doubt should be supplied when challenging it - an anti-skeptical point similar to Horton's, which reflects the pragmatist spirit of her argument.

Reiterating the political predicament in this way-in terms of distinguishing between normality and exception-enables Pitkin to direct attention to the complexity of political judgment as a lived experience (Pitkin, 1966: 49-52). In any political situation, and from anyone's perspective, the question can arise: is this normal, or exceptional (legitimate or illegitimate, genuine or spurious)? Pitkin suggests that there may be no way to secure these distinctions. Nothing she says settles the question, but she suggests that the point may be not to settle it:

Each individual does and must ultimately decide for himself and is responsible for his decision; but he may make a wrong decision and thereby fail to perform his obligations. But then who is to say someone has made a wrong decision? Anyone can say, but not everyone who cares to say will judge correctly; he may be right or wrong. And who decides that? [...] Each of us who talks or thinks or acts with regard to the situation assesses it, and no theory or God or Party can get us off that hook. [...] No one has the last

\footnotetext{
${ }^{13} \mathrm{Cf}$. Brandom on "the default and challenge structure of entitlement" (1994: 176-178).
} 
word because there is no last word. But to make that clear, one would have to say a great deal more about how language functions and why we are so persistently inclined to suppose that there must be a last word. (Pitkin, 1966: 52) ${ }^{14}$

In the subsequent literature on political obligation, Pitkin's essay is almost universally misread as presenting the so-called conceptual argument for the existence of political obligations - a reading that tries to make her fit the normativist picture of political obligation she tries to get away from, and then to show how her account fails according to its standards. Contrary to her intentions, this treats her as if she wants to preclude critical scrutiny of the relations of power in which political subjects find themselves. By pointing to the grammar of our political language and away from the problem of grounding obligations, Pitkin intends to issue a reminder of the predicament faced by actual political subjects as a lived experience: the task of political judgment — assessing whether the situation is normal or exceptional, whether our apparent obligations are genuinely binding, whether the political authority we face is legitimate or merely purports to be so. But what does it mean to see this predicament as a lived experience?

\section{$4 \quad$ The pragmatic turn}

Pitkin's focus on the grammar of political obligation intimates an alternative way of thinking about political obligation, in which the problem is not to be resolved philosophically, but addressed politically. Before exploring further what this means, however, it will be helpful to reflect a bit more on the question why her essay is so

\footnotetext{
${ }^{14}$ She follows up on the suggestion that political theorists should think more about language in Pitkin (1972).
} 
often seen as a (flawed) attempt to resolve or dissolve the predicament. To some extent this may be attributed to some formulations that are less than fully clear, and perhaps to a similarity of her view to others that are more plausibly interpreted as versions of the so-called conceptual argument. ${ }^{15}$ More importantly, Pitkin's critics seem to assume that when she says that "to call something a legitimate authority is normally to imply that it ought to be obeyed," she purports to dismiss the predicament that subjects confront in the face of authority as a genuine question. If one presupposes a task-description of political philosophy in which resolving political questions by providing applicable principles is the main demand on political thinking, her view that 'this is what the words mean' must appear as a dismissal of the question whether and why we ought to obey political authority, rather than an elucidation of the problem. But to understand both why this is not the point of her focus on the "grammar" of the concepts, and why it is nonetheless often taken as such, we need a better grasp of the views of meaning in play here.

Let's try (in line with Pitkin) to suspend the normativist picture of our task, at least for the moment, and switch the question: rather than is there an obligation to obey', and 'how is it justified?' we ask: 'What is it we do when we take someone to be obligated to obey political authority?' And: 'What is it we do in practice when we distinguish between spurious and genuine political obligations, between a mere sense of obligation and the 'real thing'?' In other words, let's shift our attention from the semantics of political obligation (the meaningful content of claims about obligations), to its pragmatics (the actions such claims perform).

At this point we can distinguish two broad strategies for providing an account of the pragmatics of political obligation, which crucially depend on our theory of

\footnotetext{
${ }^{15}$ See notes 9 and 10 above.
} 
meaning. On one type of approach to the theory of meaning, 'representationalism', we should understand the meaning of a claim in terms of its reference to some state of affairs. ${ }^{16}$ What is actually the case about this state of affairs determines the truth conditions of the claim. Applying this in the case of 'obligations', one may then suggest that when we hold someone to be obligated to obey, we signal or describe some moral truth or property about that person, or more precisely about the relation between that person and a form of authority. (Recall Simmons' characterization of the problem as that of "explaining the nature and scope of such special moral bonds (if any such exist), and of determining who, if anyone, is constrained by them" (Simmons, 1979: 3-4)). Once we know the nature of political obligation, we can formulate the truth conditions of claims and judgments about obligations in a theory, and use that to assess whether actual claims and judgments about political obligations are correct or incorrect. (For example, one might argue that the nature of political obligations is such that they arise from consent, and then conclude that most people have no political obligations (Simmons, 1979).) This line of approach focuses on the semantics of claims or judgments about political obligation - the study of its content — and treats this as prior to its pragmatics — the study of its use. What it is for someone to be obligated (or to have an obligation) is prior to, or can be understood independently of, what it is for someone to be taken to be or treated as obligated. Understood in this way, our language seems to commit us to the idea that there must be a distinct, theoretically identifiable form of knowledge that enables us to distinguish in practice between genuine and spurious obligations (or, if such knowledge is unavailable, the distinction is unintelligible). Usually this

\footnotetext{
${ }^{16}$ In this paragraph I loosely follow Brandom (2000: 7-10).
} 
representationalist view of language remains implicit and unquestioned in debates about political obligation. ${ }^{17}$

Pitkin's account of political obligation (and of the philosophical task with respect to it) is informed by a very different view of meaning. It turns crucially on an insight about language she adopts from Wittgenstein: that the meaning of concepts is to be understood in terms of their use in social practice (Wittgenstein, 2001). This idea is at the heart of a broad shift in orientation in philosophy, sometimes called "the pragmatic turn" (Bernstein, 2010; Egginton \& Sandbothe, 2004; Rehg \& Bohman, 2001). ${ }^{18}$ To my mind, the most systematic articulation of this turn in thinking about language and meaning is offered by Robert Brandom (1994). ${ }^{19}$ On his account, the central notion that makes sense of meaning is not "representation," but “expression." 20 This expressivist theory of language

“[...] approaches the contents of conceptually explicit propositions or principles from the direction of what is implicit in practices of using expressions and acquiring and deploying beliefs. [...] The sort of pragmatism adopted here seeks to explain what is asserted by appeal to features of assertings, what is claimed in terms of claimings, what is judged by judgings, and what is believed by the role of believings (indeed, what is expressed by

\footnotetext{
${ }^{17}$ Of course, considerations about language are common in meta-ethics. For a defense of a representationalist account of language in the context of a more general meta-ethical theory, see Copp (1995). Approaching the point from a meta-ethical perspective, however, would presuppose from the start that political obligation must be understood in moral terms.

${ }^{18}$ Classical treatments include Putnam (1995), Habermas (1992), Rorty (1979).

${ }^{19}$ See also Brandom (2000, 2009). I am also indebted to J Anderson (2008), Lance \& White (2007), M Williams (2004). I provide a more in-depth discussion of the relevance of Brandom's thought for political theory in Fossen (forthcoming a), and develop a pragmatist account of political legitimacy in Fossen (forthcoming b).

${ }^{20}$ This is not to say that concepts cannot be used to represent states of affairs, but that this relation of reference is not a fruitful starting point for explaining their meaning.
} 
expressings of it) - in general, the content by the act, rather than the other way around." (Brandom, 2000: 4)

In other words, Brandom reverses the order of explanation compared to representational theories of language: "semantics must answer to pragmatics" (Brandom, 1994: 83, 145).

Pragmatist approaches to language such as Brandom's try to explain the correctness of applications of concepts (what words really mean) in the first instance in terms of their use (how they are treated by those who deploy them), rather than in terms of their relation of reference to the world. ${ }^{21}$ In this vein, Brandom argues that concepts have their point and purpose in social practices that are implicitly normative. In his vocabulary, participants in social practices are engaged in "deontic scorekeeping", where each keeps multiple sets of books that track the commitments and entitlements of others and themselves (Brandom, 1994: 166). Commitment and entitlement are the basic normative statuses that participants attribute to one another (and themselves); they are what one might call the currency of social practice, brought into play through mutual engagement among a plurality of participants. From each participant's perspective, the significance of a commitment is assessed against a background repertoire of further commitments, and these repertoires always to some extent differ and conflict. Being committed is a matter of first and second-personal holding to account, not a third-personal state of affairs. ${ }^{22}$ The attitude of taking or treating someone as committed is primary; the status of being committed depends on this. ${ }^{23}$ Much of individuals' mutually holding each other to account is a matter of

\footnotetext{
${ }^{21}$ For an overview, see Loeffler (2009).

${ }^{22}$ For an elaboration of a similar idea as the basis for morality, see Darwall (2009).

${ }^{23}$ In fact the relation between normative statuses and practical attitudes is complicated, because Brandom holds both that social practice is irreducibly normative, and that normative
} 
implicitly treating one another as committed to do and to believe various things, although normative statuses can be made explicit and disputed in a game of giving and asking for reasons. We should distinguish between commitments that a participant acknowledges and commitments that she undertakes but fails to acknowledge (from the perspective of another scorekeeper, or reflexively of herself). What one is really committed to, and whether one is entitled to one's commitments, is determined from a multiplicity of perspectives in an ongoing, open-ended process of action and response.

Political obligations, from this perspective, are simply the kinds of practical commitments subjects and authorities attribute to and withhold from one another in the context of subject-authority relations. They express the idea that subjects and authorities hold one another (and themselves) responsible, treating certain courses of action as appropriate and others as inappropriate. Most of the literature on political obligation focuses on the obligation to obey, which may be construed as a commitment on the part of subjects to take what authority issues as reasons for action, perhaps accompanied by an entitlement on the part of authority to sanction them if they fail to comply. But relations between subjects and authorities can involve a range of other commitments, depending on the form these relations take. For example, in some circumstances, citizens are taken to have duties of military service or to turn out in elections. Bhikhu Parekh argues that citizenship includes "an obligation to take an active interest and to participate in the conduct of public affairs, to keep a critical eye on activities of the government, to speak up against the injustices of their society, to stand up for those too demoralized, confused and powerless to fight for themselves, practice. For an explanation of this relation as an inherent tension in practical engagement, see Fossen (forthcoming a). 
and in general to help create a rich and lively community" (Parekh, 1993: 243). In certain situations, subjects may even be said to have duties to resist (illegitimate) authorities. ${ }^{24}$ These remarks are merely illustrative; for reasons to be discussed shortly, my aim is not to give a substantive account of the content of political commitments. The point here is that the question at stake is not 'are there political obligations?' in abstraction, but rather 'in which ways can political subjects and authorities appropriately hold one another responsible in this specific situation?'

This brief account of the language-theoretical underpinnings of different ways of framing the predicament of subjects in the face of political authority helps to clarify the point of Pitkin's classic essay. When she says that it is part of the meaning of the terms that a legitimate authority is one that ought to be obeyed, this is not in the first instance a point about semantics but pragmatics. "You cannot, without further rather elaborate explanation, maintain simultaneously both that this government has legitimate authority over you and that you have no obligation to obey it." (Pitkin, 1966: 39) The reason is that to say that an authority is legitimate is to articulate a particular practical stance toward it: to express a commitment to recognize it as authoritative. It is just an aspect of what we are doing when we say that a political authority is legitimate, that we hold that it ought to be obeyed by those subject to it.

But that, as Pitkin realized, is not to provide criteria for distinguishing in practice. Still, I think she intimates (but does not develop) a different view of political judgment, where this is not a matter of applying philosophically secured moral knowledge but rather a kind of practical engagement. What does this mean? Pitkin does not offer much in the way of an answer to this question, but we can go at least a

\footnotetext{
${ }^{24}$ Pitkin is, as always, perceptive on this point (1966: 41-42).
} 
bit further by connecting Brandom's account of practical commitments with some recent strands of political theory.

\section{$5 \quad$ Contesting commitments}

We can get a better sense of what it is to distinguish in practice between genuine and spurious political obligations by raising two crucial questions about them, concerning their content and justification. ${ }^{25}$ The question of content asks what it is that a political obligation commits one to do. What implications does it have? In pragmatic terms: what courses of action does it render appropriate or inappropriate? The question of justification concerns the propriety of particular attributions of political commitments. By virtue of what (if anything) can one be entitled to attribute certain political commitments rather than others (to oneself or to others)? What considerations count as good reasons for attributing particular political commitments? Or, to put it in different terms, how does one know whether a sense of political obligation (or lack thereof) is genuine, rather than spurious?

This is where the difference between the normativist and pragmatist pictures of political obligation becomes salient. For a normativist, these are precisely the sorts of questions that call for a theoretical solution in the form of philosophically justified principles of political obligation. From a normativist perspective, political judgment — by which I mean the task of distinguishing between genuine and spurious

\footnotetext{
${ }^{25}$ In Brandomian terms, since commitments stand in inferential relations to other commitments, the question of justification asks for the articulation of "upstream" commitments (in light of which someone is entitled or not to a commitment), and the question of content asks for the "downstream" commitments (the beliefs and actions that particular commitment licenses) (Brandom, 2000: 193-194).
} 
political obligations in a concrete situation - appears as a matter of applying philosophically grounded principles to the particular case. Such practical application can clearly be difficult, for instance if the particulars of the case are unclear, or if special circumstances bring in conflicting (moral) considerations. Still, the validity of the relevant principles in a satisfactory theory of political obligation is philosophically grounded, making them in principle external to or independent of practical engagement. ${ }^{26}$

A pragmatist account of political obligation, in contrast, implies that such a strong separation of justification and application is problematic. The distinction between genuine and spurious commitments cannot be philosophically secured. Disputing commitments is making explicit and altering the normative scores among a plurality of perspectives, not discovering and communicating an independently real or true score. If that is the case, the content and justification of these commitments cannot be spelled out in advance of actual engagement in practice and codified in a form of general and abstract knowledge; it is rather to be assessed and contested in the actual play of relations. What counts as good reasons for certain political commitments, and what counts as living up to one's commitments, is provisionally determined in medias res, through the engagements of participants, and from different and potentially conflicting perspectives. Crucially, then, the pragmatist framing of the predicament proposed here implies acknowledgment of the contestability of the content and justification of political commitments. This is why "[n]o one has the last word because there is no last word" (Pitkin, 1966: 52; cf. Brandom, 1994: 601; Fossen, forthcoming a: 8-16). Little can be said about political commitments in

\footnotetext{
${ }^{26}$ There is thus a sense in which normativism, in Bernard Williams' apt phrase, places "morality prior to politics" (2005).
} 
abstraction from a substantive, contextual, and contestable interpretation of the political situation at stake. The bottom line is that political judgment-by which I mean distinguishing in practice between genuine and merely felt obligations, legitimate and illegitimate authority, or normal and exceptional politics - is not a matter of applying externally or independently justified principles, but rather a radically situated kind of attunement to a situation and engagement with others.

Two responses are likely to be raised at this point. On the one hand, one might accept this pragmatist framing of the political predicament, but suggest that it does not make much difference. After all, as political subjects we still face the predicament of deciding what stance to take; whether we are committed to obey and uphold the authorities we face. So one reply would be to say that the task of theoretically formulating and justifying principles of political obligation should be seen as embedded within actual political practices, rather than as seeking a standpoint independent of them. On this view, the theorist offers principles not as privileged prescriptions that political subjects ought to apply in practice, but as recommendations offered by one political subject to another according to which each can decide for him- or herself. ${ }^{27}$ Reframing the predicament in pragmatic terms changes little, according to this line of thinking: the formulation and justification of principles of political obligation remains the crucial task of political philosophy in the face of this political predicament, though this is now seen as a more contextual activity. On the other hand, if one grants that this approach does not leave the normativist endeavor unscathed, it may seem that a pragmatist explication of the

\footnotetext{
${ }^{27}$ As Rutger Claassen puts the point (2011), normative political theorists are not "philosopher-kings," pretending to impose definitive answers on political subjects, but "philosopher-citizens," offering up their principles and criteria within ongoing political practices, for others to take up as they see fit.
} 
predicament without reference to grounding principles leaves subjects incapable of deciding, pulling away any ground for doing so. It may appear that there is nothing more to be said, and so no task left for political philosophy with respect to political obligation, leaving subjects to sort things out for themselves.

I believe these responses are both one-sided. The first, reconciliatory response sees that situated subjects can still engage in a game of giving and asking for reasons, and seeks to participate in articulating and disputing commitments. That is important, but it fails to fully acknowledge the potentially unsettling character of political contestation. The second, defeatist response acknowledges but overreacts to the contestatory character of political commitments. The fact that this pragmatist line of thinking does not provide subjects with secure, applicable knowledge that resolves the political predicament does not render judgment groundless, nor theorizing pointless. In closing, I want to illustrate these points by considering some recent currents of political theory that draw attention to conditions of politics which both enable political judgment - as a fund of reasons on which we can draw in disputing commitments-while at the same time potentially unsettling it - as an irreducible dimension of political contestation.

Pitkin already intimates one direction in which to look. As we've seen, she argues that a subject who faces authorities would do well to "look to the nature of the government - its characteristics, structure, activities, functioning," rather than to his or her own prior consent (Pitkin, 1966: 40). To put this point a bit differently, at least part of what is at stake in this predicament is the interpretation of the political situation in which one finds oneself, and in particular the question how to understand the forms of power one faces. This is a problem of representation: one can only get a grip on the situation by seeing those forms of authority as something-say, a 
parliamentary democracy or a police state. In a recent analysis of the concept of political representation, Michael Saward argues that "representation" needs to be understood in light of an ongoing practice of claim-making: "representing is a constitutive activity, one that centrally involves offering constructions or images of constituents to constituents and audiences." (Saward, 2010: 14) In other words, representations need to be understood in terms of how they are used. Saward's pragmatic analysis seems as relevant to the representation of the political order to subjects (by the authorities and by subjects themselves), as to the sense of political representation in which certain political actors stand or act for others (such as the elected and the electorate). If such a pragmatic analysis of representation is convincing, and representations of authorities are themselves at stake in the situation, then picturing them a certain way rather than another is never neutral, but is bound up with the content and justification of our political commitments. Representing authority in one way rather than another warrants application of further terms, fosters expectations of the behavior of authority, affects perceptions of likely consequences of one's own actions, and has implications for what stance it would be appropriate to take. So the question of the nature of the object of political commitments cannot be treated as a matter of mere definition; terms like 'state', 'government', 'law', and 'democracy' come to mean something only in being used in certain ways in certain practices. Neither is it a matter of straightforwardly getting the facts right by means of accurate observation from a disengaged standpoint, to which one can subsequently apply independent principles or criteria. Rather, subjects face a task of perspectival explication of power-relations in ongoing action and response with others. ${ }^{28}$

\footnotetext{
${ }^{28}$ This is (in part) what I take to be the point of genealogy in political theory. See, for instance Tully (2002), Owen (2003).
} 
Still, pace Pitkin, there is also a sense in which the question whether one is committed to obey or resist authority draws attention to one's self-understanding. Political commitments are constitutive of one's political identity, part of who one is. And since, on a pragmatic understanding of identity, who one is is not entirely up to oneself, this involves an orientation toward concrete others. Disputing political commitments is disputing one's self-understanding as well as the terms of political association (including who counts as associated) with others. In this vein, David Owen, drawing on Stanley Cavell, argues that "it is through the exercise of one's political voice that one discovers (ongoingly) where one stands politically (the limits of that to which one can assent) and how one stands politically in relation to others (the depth and extent of one's agreement with others)" (Owen, 1999: 587; Norval, 2009: 171). This gives place to the notion of 'consent,' not as a normative principle that grounds obligations, but rather as an ontological condition of political commitment: in the same way that a subject finds herself confronted by authority and is forced in that sense to take a stance toward it, so an authority finds itself facing potentially unruly subjects who always have the possibility to refuse to acknowledge the political commitments it attributes to them (cf. Tully, 1999). As Owen states:

"Indeed, it is precisely in the agonic play of assent and dissent that the content of political consent is negotiated - and, concomitantly, it is in discovering how I stand to the content of political consent that I work out the depth and extent of my community with my fellow citizens. This is to say that it is in the process of negotiating the content of political consent that I forge my political identity." (Owen, 1999: 587)

Of course, most of us don't reflect daily on what it means to see ourselves as citizens, for example; but the significance of being a citizen (and being taken and treated as a 
citizen, or denied that status), whatever that means in a particular context, can be made explicit and disputed in critical moments.

Understood in this way, political commitments are in a sense like "associative political obligations"-obligations one has in virtue of being a member of a political community, for instance duties of citizenship in a state. But, importantly, this associative character is understood here in dynamic and perspectival terms. This contrasts, for instance, with the way Margaret Gilbert articulates the idea of associative political obligations. On her account, someone has political obligations if a "joint commitment" to membership in society "exists" or is "in place." A joint commitment is created by the acts of will of the members (Gilbert, 2006: 134-146). Yet on that way of thinking about commitments, the predicament of distinguishing in practice between genuine and merely attributed obligations appears as an epistemic one of describing individuals' mental states accurately. It is hard to see what it would be to politically dispute such commitments on Gilbert's account. In contrast, on a pragmatist order of explanation, the status of being committed depends on a socioperspectival holding or taking someone to be committed. The question whether one is really, fully, genuinely a member of the political community and what this commits one to do cannot be assessed from a disengaged, third-person perspective. The community is not a prior ground of political obligations; it is constituted and reconstituted in the ongoing engagement of subjects and authorities (cf. Frank, 2010; van Roermund, 2003).

What I'm trying to suggest is that Pitkin's turn to the nature of the government and associativists' attention to membership of a political community respond to two different but equally important conditions of politics that have a crucial role in disputing political commitments. On the pragmatic reframing of the predicament I 
have outlined, the content and justifications of political commitments do not constitute a distinct form of knowledge that can be philosophically secured, but are bound up with the conditions of politics, including the role of representations of authority and individual and communal self-understandings. ${ }^{29}$ If, as the currents of political theory on which I have drawn suggest, these conditions are both constitutive our political commitments and essentially subject to political contestation, then political judgment has inherent limits, which philosophy cannot resolve, but should rather acknowledge and articulate. Engaging in political practice renders our sense of identity vulnerable to the eyes and performances of others (as well as our own critical reflection) (Markell, 2003). And while representations of authority enable subjects to articulate the significance of political commitments in various ways, they remain provisional, situated within an ongoing dynamic of action and response in which someone might unmask them, exposing us to uncertainty. So, without providing directly applicable answers, (to echo Pitkin once again) this approach can at least tell us where to look, calling on us to make explicit the ways in which the political predicament presents itself and engages us, and drawing attention to the conditions and limits of political judgment.

\footnotetext{
${ }^{29}$ This account is not meant to be exhaustive. A further direction of inquiry might draw attention, for example, to the significance of the uptake of events for political commitments. Arguably, both local, immediate events and large-scale and historical events have a constitutive yet contested significance for political commitments, both for understanding the immediate situation and for the wider constellation of meaning (or in Brandomian terms the wider repertoires of commitments) within which the political predicament arises.
} 
In this essay, I've sought to contrast the traditional normativist way of framing the problem of political obligation with an alternative framing drawn out of pragmatist currents of political theory and philosophy. From this perspective, political obligations are practical commitments that come into play through participants' mutually holding each other to account in political practices. If this account is compelling, its upshot is to broaden the scope of philosophical inquiry in the face of the predicament that subjects confront in the face of authority, from a narrow focus on the search for normative principles that ground political obligations, towards the task of articulating the forms of practical involvement through which the content and justification of political commitments can be determined and contested. Reframing political obligation in this way draws our attention to the conditions in which the question appears as a lived, practical predicament. To judge well (whatever that may be), from this perspective, is not simply to correctly apply independently justified principles to a particular case, but to exhibit a kind of practical mastery in attuning oneself to various aspects of a political situation. Clearly, much more needs to be said as to what this involves, exactly. But reframing the predicament in pragmatic terms, as I propose, enables us to pursue this line of enquiry, and to see this as integral to what is at stake in the problem of political obligation

Of course, I've only shown that this perspective is available and perhaps plausible, not that it is correct. Nor have I refuted the normativist approach. Still, by offering a contrasting perspective, my argument should at least undermine the selfevidence of the normativist framing of the problem of political obligation. It's worth mentioning, in closing, that this pragmatic picture of political obligation does not to deny theory a role in articulating criteria of judgment. At their best, normative 
theorists contribute to the perspectival articulation, clarification, systematization, and disputing of political commitments and their consequences. John Horton's recent work is an example of an attempt to shift the task of political philosophers from securing political obligations to critical articulation of the sense of political identification of citizens, without giving up on critical argumentation. Similarly, though more negatively, Pitkin argued against consent theory that it is not very suitable as a standard that articulates what is at stake when facing a concrete form of political authority: one's own prior express or tacit consent does not seem to address what is at stake-whether the government is such that one ought to consent to it. One might call this view of non-normativist normative theorizing an ethics of critical articulation - an effort of making explicit the norms to which we commit ourselves as political subjects in the political relations in which we find ourselves (cf. E Anderson, 1998: 15; Vincent, 2004: 321-326; Walzer, 1987; B Williams, 1985). But it is important to emphasize that we can make the political predicament intelligible without addressing it from the start in a moral register; it is approached here in the first instance as a political question. Morality comes in (insofar as it does), not in rendering the predicament intelligible but as one possible, universalistic mode of selfunderstanding. Articulating the predicament in this way thus achieves a measure of independence between political and moral philosophy. 


\title{
Acknowledgments
}

For helpful discussions, comments, and criticisms of this paper at various stages of development, I would like to thank Joel Anderson, Bert van den Brink, Robin Celikates, Rutger Claassen, Wout Cornelissen, Patchen Markell, Dorota Mokrosińska, Johan Olsthoorn, David Owen, Bruno Verbeek, Evert van der Zweerde and the participants of the Political Theory Panel at the Politicologenetmaal in Leuven, as well as several anonymous referees.

\begin{abstract}
About the author
Thomas Fossen is postdoctoral fellow in political philosophy at Leiden University. He works on the NWO-funded collaborative project 'Between Deliberation and Agonism: Rethinking Conflict and its Relation to Law in Political Philosophy.' $\mathrm{He}$ has previously published papers on political legitimacy, agonistic political theory, Brandom's pragmatism, and Nietzsche's aristocratism.
\end{abstract}




\section{References}

Anderson E (1998) Pragmatism, Science, and Moral Inquiry. In: Fox RW and Westbrook RB (eds), In Face of the Facts, Cambridge, Cambridge University Press, pp. 10-39.

Anderson J (2008) Disputing Autonomy: Second-Order Desires and the Dynamics of Ascribing Autonomy. Sats - Nordic Journal of Philosophy, 9(1), 7-26.

Bernstein RJ (2010) The Pragmatic Turn. Cambridge, Polity.

Brandom R (2000) Articulating Reasons: An Introduction to Inferentialism. Cambridge, MA, Harvard University Press.

Brandom R (1994) Making It Explicit: Reasoning, Representing, and Discursive Commitment. Cambridge, MA, Harvard University Press.

Brandom R (2009) Reason in Philosophy: Animating Ideas. Cambridge, MA, Harvard University Press.

Buchanan A (2002) Political Legitimacy and Democracy. Ethics, 112(4), 689-719.

Claassen R (2011) Making Capability Lists: Philosophy versus Democracy. Political Studies, 59(3), 491-508.

Copp D (1995) Morality, Normativity, and Society. New York, Oxford University Press.

Dagger R (2000) Membership, Fair Play, and Political Obligation. Political Studies, 48(1), 104-117.

Dagger R (2007) Political Obligation. Stanford Encyclopedia of Philosophy, Available from: http://plato.stanford.edu/entries/political-obligation/ (accessed 3 December 2009).

Darwall S (2009) The Second-Person Standpoint: Morality, Respect, and Accountability. Cambridge, MA, Harvard University Press.

Egginton W and Sandbothe M (eds) (2004) The Pragmatic Turn in Philosophy: Contemporary Engagements Between Analytic and Continental Thought. Albany, State University of New York Press.

Flathman RE (1972) Political Obligation. Atheneum.

Fossen T (forthcoming a) Politicizing Brandom's Pragmatism: Normativity and the Agonal Character of Social Practice. European Journal of Philosophy.

Fossen T (forthcoming b) Taking Stances, Contesting Commitments: Political Legitimacy and the Pragmatic Turn. Journal of Political Philosophy.

Frank J (2010) Constituent Moments: Enacting the People in Postrevolutionary America. Duke University Press. 
Geuss R (2008) Philosophy and Real Politics. Princeton, Princeton University Press.

Gewirth A (1970) Obligation: Political, Legal, Moral. In: Pennock JR and Chapman JW (eds), Nomos XII: Political and Legal Obligation, New York, Atherton.

Gilbert M (2006) A Theory of Political Obligation: Membership, Commitment, and the Bonds of Society. Oxford, Oxford University Press.

Glock H-J (1996) A Wittgenstein Dictionary. Oxford, Blackwell.

Green L (1990) The Authority of the State. Oxford, Oxford University Press.

Habermas J (1992) Postmetaphysical Thinking: Philosophical Essays. Cambridge, MIT Press.

Horton J (2007a) Defending Associative Political Obligations: A Response to Richard Vernon. Political Studies, 55(4), 880-884.

Horton J (2006) In Defence of Associative Political Obligations: Part One. Political Studies, 54(3), 427-443.

Horton J (2007b) In Defence of Associative Political Obligations: Part Two. Political Studies, 55(1), 1-19.

Horton J (2010) Political Obligation. 2nd edition. Basingstoke, Palgrave Macmillan.

Horton J (1992) Political Obligation. Basingstoke, Macmillan.

Klosko G (2011) Are Political Obligations Content Independent? Political Theory, 39(4), $498-523$.

Knowles D (2009) Political Obligation: A Critical Introduction. London, Routledge.

Laden AS (2001) Reasonably Radical: Deliberative Liberalism and the Politics of Identity. Ithaca, Cornell University Press.

Lance $M$ and White H (2007) Stereoscopic Vision: Persons, Freedom, and Two Spaces of Material Inference. Philosopher's Imprint, 7(4), 1-21.

Loeffler R (2009) Neo-Pragmatist (Practice-Based) Theories of Meaning. Philosophy Compass, 4(1), 197-218.

Macdonald M (1940) The Language of Political Theory. In: Proceedings of the Aristotelian Society, Harrison \& Sons, pp. 91-112.

Markell P (2003) Bound by Recognition. Princeton, Princeton University Press.

McPherson T (1967) Political Obligation. London, Routledge.

Mokrosinska D (2012) Rethinking Political Obligation. Basingstoke, Palgrave Macmillan.

Morris CW (1998) An essay on the modern state. Cambridge, Cambridge University 
Press.

Norval AJ (2009) Passionate subjectivity, contestation and acknowledgement: Rereading Austin and Cavell. In: Schaap A (ed.), Law and Agonistic Politics, Farnham, Ashgate, pp. 163-177.

Owen D (1999) Cultural Diversity and the Conversation of Justice: Reading Cavell on Political Voice and the Expression of Consent. Political Theory, 27(5), 579596.

Owen D (2003) Genealogy as Perspicuous Representation. In: Heyes CJ (ed.), The Grammar of Politics: Wittgenstein and Political Philosophy, Ithaca, Cornell University Press, pp. 82-96.

Parekh B (1993) A Misconceived Discourse on Political Obligation. Political Studies, 41(2), 236-251.

Pateman C (1973) Political Obligation and Conceptual Analysis. Political Studies, 21(2), 199-218.

Pateman C (1979) The Problem of Political Obligation: A Critical Analysis of Liberal Theory. New York, Wiley.

Pitkin H (1965) Obligation and Consent--I. American Political Science Review, 59(4), 990-999.

Pitkin H (1966) Obligation and Consent--II. American Political Science Review, 60(1), 39-52.

Pitkin H (1972) Wittgenstein and Justice: On the Significance of Ludwig Wittgenstein for Social and Political Thought. Berkeley, University of California Press.

Putnam H (1995) Pragmatism: An Open Question. Oxford, Blackwell.

Rehg W and Bohman J (2001) Pluralism and the Pragmatic Turn: The Transformation of Critical Theory. Cambridge, MA, MIT Press.

Rorty R (1979) Philosophy and the Mirror of Nature. Princeton, Princeton University Press.

Rorty R (1991) The Priority of Democracy to Philosophy. In: Objectivity, Relativism, and Truth: Philosophical Papers, vol. 1, Cambridge, Cambridge University Press, pp. 175-196.

Saward M (2010) The Representative Claim. Oxford University Press.

Simmons AJ (1996) Associative Political Obligations. Ethics, 106(2), 247-273.

Simmons AJ (1979) Moral Principles and Political Obligations. Princeton, Princeton University Press.

Simmons AJ (2001) Philosophical Anarchism. In: Justification and Legitimacy: 
Essays on Rights and Obligations, Cambridge, Cambridge University Press, pp. 102-121.

Stark CA (2000) Hypothetical Consent and Justification. The Journal of Philosophy, 97(6), 313-334.

Tully J (2002) Political Philosophy as a Critical Activity. Political Theory, 30(4), $533-555$

Tully J (1999) The Agonic Freedom of Citizens. Economy and Society, 28(2), 161182.

Van der Vossen B (2011) Associative Political Obligations. Philosophy Compass, $6(7), 477-487$.

Van Roermund B (2003) First-Person Plural Legislature: Political Reflexivity and Representation. Philosophical Explorations, 6(3), 235-250.

Vernon R (2007) Obligation by Association? A Reply to John Horton. Political Studies, 55(4), 865-879.

Vincent A (2004) The Nature of Political Theory. Oxford, Oxford University Press.

Walzer M (1987) Interpretation and Social Criticism. Cambridge, MA, Harvard University Press.

Williams B (1985) Ethics and the Limits of Philosophy. Cambridge, Harvard University Press.

Williams B (2005) In the Beginning was the Deed: Realism and Moralism in Political Argument. Princeton, Princeton University Press.

Williams M (2004) Context, Meaning, and Truth. Philosophical Studies, 117(1), 107129.

Wittgenstein L (2001) Philosophical Investigations. Oxford, Blackwell. 